\title{
Effects of Combined or Along VFA, pH, Lipopolysaccharide and Histamine on the Rumen Epithelial Permeability of Dairy Goats In Vitro
}

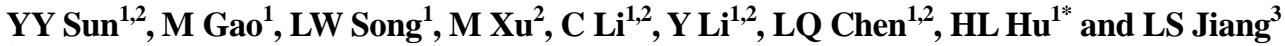 \\ ${ }^{1}$ Institute of Animal Nutrition and Feed, Inner Mongolia Academy of Agricultural \& Animal Husbandry Sciences, Hohhot, \\ Inner Mongolia, 010031, P. R. China \\ ${ }^{2}$ College of Animal Science, Inner Mongolia Agricultural University, Hohhot, Inner Mongolia, 010018, P. R. China \\ ${ }^{3}$ Beijing Key Laboratory of Cow Nutrition, College of Animal Science and Technology, Beijing University of Agriculture, \\ Beijing, 102206, P. R. China \\ *For correspondence: honglianhu2010@163.com
}

Received 10 December 2020; Accepted 27 March 2021; Published 10 June 2021

\begin{abstract}
This study investigated whether concurrent presence of lipopolysaccharide (LPS) and histamine (HIS) have the potential to increase permeability of the ruminal epithelium at physiological $\mathrm{pH}$ and acidotic ruminal $\mathrm{pH}$. Nine 2.5-year-old female lactating Saanen dairy goats $(42.79 \pm 5.61 \mathrm{~kg}$ of BW; Mean \pm SD) were used as a ruminant model. ruminal epithelium of goats were collected and mounted in Ussing chambers on their mucosal side in different gradient buffer solutions (pH 7.4, 5.5 and 5.2) containing LPS $\left(0,30\right.$ and $\left.60 \mathrm{KEU} \cdot \mathrm{mL}^{-1}\right)$ or HIS $\left(0,0.5\right.$ and $\left.10 \mathrm{ng} \cdot \mathrm{mL}^{-1}\right)$. The rumen epithelial electrophysiological indexes, such as short-circuit $\left(\mathrm{I}_{\mathrm{sc}}\right)$, tissue conductance $\left(\mathrm{G}_{\mathrm{t}}\right)$ and the permeability of marker molecules of different sizes (horseradish peroxidase, HRP and fluorescein 5(6)-isothiocyanate, FITC) from the mucosal to the serosal side, were measured. Both $\mathrm{I}_{\mathrm{sc}}$ and $\mathrm{G}_{\mathrm{t}}$ were increased, accompanied by enhanced flux of FITC, with a decrease of mucosal $\mathrm{pH}(P<0.05)$. The addition of LPS at mucosal $\mathrm{pH} 5.2$ significantly increased $\mathrm{I}_{\mathrm{sc}}, \mathrm{G}_{\mathrm{t}}$ and FITC flux rates and decreased potential difference (PD) $(P<0.05)$. Additionally, the concurrent presence of LPS and HIS at both physiological and acidotic ruminal pH also significantly increased the permeability of ruminal epithelium as evidenced by increasing $\mathrm{I}_{\mathrm{sc}}$, $\mathrm{G}_{\mathrm{t}}$ and FITC flux rates and decreasing PD. In summary, our results have shown that concurrent presence of LPS $60 \mathrm{KEU} \cdot \mathrm{mL}^{-1}$ and $\mathrm{HIS} 10 \mathrm{ng} \cdot \mathrm{mL}^{-1}$ at mucosal pH 5.5 can increase the permeability of ruminal epithelium. The combination of low pH and both high LPS and HIS may increase vulnerability to aggravated rumen epithelial barrier dysfunction. (C) 2021 Friends Science Publishers
\end{abstract}

Keywords: Subacute rumen acidosis; Rumen epithelial permeability; pH; Lipopolysaccharide; Histamine

\section{Introduction}

Subacute ruminal acidosis (SARA) is a common nutritional metabolic disease involved in ruminant production. It has a great impact on the long-term health and production efficiency of animals (Danscher et al. 2015). In recent years, in order to improve the production efficiency of ruminants and the quality of animal products, researchers have conducted extensive research on the adverse effects of SARA on intensive ruminant production systems. Reports indicate that ruminants fed rapidly fermentable carbohydrates for a long time will develop an excessive accumulation of organic acids in the rumen, and a dramatic decline of rumen $\mathrm{pH}$, further producing a variety of abnormal metabolites such as HIS and LPS (Liu et al. 2013). These toxic and harmful substances can be absorbed into the blood, which in turn causes a systemic inflammatory response (Sun 2017) and ultimately induces SARA with loss of appetite, laminitis and diarrhea (Plaizier et al. 2012). Evidence suggests that rumen LPS is produced by Gramnegative bacteria (Khafipour et al. 2009; Wang et al. 2015). When ruminants suffer from SARA, Gram-negative bacteria in the rumen rupture and cell lysis releases a large amount of LPS, which can compromise rumen epithelial barrier function (Liu et al. 2013; Sato 2016). The free LPS are then translocated from the rumen into the blood across the rumen epithelial barrier, increasing the concentration of blood LPS, further activating the inflammatory and acute phase responses (Dong et al. 2011). Therefore, the accumulation and translocation of LPS might cause disruption of epithelial barrier integrity in the gastrointestinal tract (Tao et al. 2014), which results in an increase in the permeability of LPS. Many researchers accept that the increase of ruminal LPS is often accompanied by the grain-induced SARA challenge (Gozho et al. 2007). HIS is an important bioactive substance and

To cite this paper: Sun YY, M Gao, LW Song, M Xu, C Li, Y Li, LQ Chen, HL Hu, LS Jiang (2021). Effects of combined or Along VFA, pH, lipopolysaccharide and histamine on the rumen epithelial permeability of dairy goats in vitro. Intl J Agric Biol 26:79-86 
also an important mediator of the inflammatory response and immune challenge (Khafipour et al. 2009). Aschenbach et al. (1998) were the first to show that application of HIS in relevant dosages $(10$ and $100 \mu \mathrm{m})$ impaired differentiation of rumen epithelial barrier integrity and function. A recent in vitro study indicated HIS could activate the inflammatory pathway of cultured rumen epithelial cells via NF-кB (Sun 2017), which has consequences for rumen epithelial integrity and function (Aschenbach et al. 2019). Taken together, SARA is known to be characterized by an increased VFA concentration, low $\mathrm{pH}$, hyperosmolarity and elevated LPS and HIS concentrations in the rumen, and these variables have some detrimental effects on the ability of the rumen epithelium to facilitate the translocation of toxic compounds such LPS and HIS (Penner et al. 2011).

Several studies conducted in cow and goat reported that SARA increased ruminal epithelial permeability and compromised rumen epithelial barrier function (Sun et al. $2018 \mathrm{~b}$ ). Previous studies have investigated the effects of low $\mathrm{pH}$ (Gaebel et al. 1989; Penner et al. 2011), hyperosmolarity (Lodemann and Martens 2006), or an exposure to toxins (Emmanuel et al. 2007) on ruminal epithelial barrier function in vitro. Greco et al. (2018) and Meissner et al. (2017) used chambers to demonstrate that a low $\mathrm{pH}$ in combination with SCFA induces damage to the rumen epithelial barrier function. While any one or a combination of these factors may affect epithelial barrier function, the extent to which LPS and HIS contribute to disruption of rumen epithelial permeability at low ruminal $\mathrm{pH}$ has not been systematically investigated. Therefore, the present study was designed to elucidate the effects of LPS and HIS on the permeability of the ruminal epithelium at physiological and acidotic luminal $\mathrm{pH}$ values, with a special focus on determining whether the co-presence of LPS and HIS can aggravate the damage of the rumen epithelial barrier elicited by low $\mathrm{pH}$.

\section{Materials and Methods}

The animal experiment protocols were approved by the Animal Care and Use Committee of The Inner Mongolia Academy of Agricultural \& Animal Husbandry Sciences and were in accordance with relevant guidelines formulated by the Ministry of Agriculture of the People's Republic of China.

\section{Animals, experimental design and treatments}

Nine 2.5-year-old female lactating Saanen dairy goats $(42.79 \pm 5.61 \mathrm{~kg}$ of $\mathrm{BW}$; Mean \pm SD) were placed in individual stalls with free access to water. Goats were fed a diet containing a non-fiber carbohydrate to neutral detergent fiber ratio (NFC/NDF) of 1.40 (NRC 2007). The nutrient compositions of the diets are presented in Table 1 . The diet ( $800 \mathrm{~g}$ dry matter per animal per day) was provided in equal amounts at $0830 \mathrm{~h}$ and $1830 \mathrm{~h}$ daily for 30 days.

\section{Rumen tissue sampling}

The dairy goats were killed by exsanguination, and ruminal tissue from the ventral sac was harvested for subsequent Ussing chamber experiments. Six ruminal epithelial tissues were collected from each goat, and every set of three ruminal epithelial tissues were included in one treatment group.

\section{Ussing Chamber Measurements}

The electrophysiological properties and permeability of the ruminal epithelium were determined for the intact ruminal epithelium using the Ussing chamber technique (Physiologic Instruments, America). Firstly, for preparation of the electrode, $2 \mathrm{~g}$ of Agarose was weighed and inserted into $50 \mathrm{~mL}$ centrifuge tubes, then $\mathrm{KCl}(150 \mathrm{~mL}, 3 \mathrm{~mol} / \mathrm{L})$ solution was added, and the centrifugal tubes were placed into $100^{\circ} \mathrm{C}$ water for $90 \mathrm{~min}$, until the liquid had a consistency of transparently sticky and there were no bubbles. The KCl-Agar solution was drawn with a $5 \mathrm{~mL}$ syringe, and a $0.5 \sim 1 \mathrm{~cm}$ length of $\mathrm{KCl}$-Agar was injected into the tip of the electrode sleeve, and then placed into $\mathrm{KCl}$ (3 mol/L) solution (Fig. 1).

A piece of ruminal epithelial tissue from the ventral sac $\left(\sim 100 \mathrm{~cm}^{2}\right)$ was rinsed by immersion in the buffer solution (Table 2). The time from the goat slaughter to mounting the epithelium was 30 45 min. The ruminal epithelium was removed from the muscle layer, placed quickly in a buffer solution kept at $37^{\circ} \mathrm{C}$, gassed with $95 \%$ $\mathrm{O}_{2}$ and $5 \% \mathrm{CO}_{2}$ and then cut into squares (about $1 \mathrm{~cm} \times 0.5$ $\mathrm{cm}$ ) and mounted in the Ussing chamber (EM-CSYS-6). The aperture area of sliders in the Ussing chamber was 0.5 $\mathrm{cm}^{2}$, which provided sufficient contact area for the ruminal epithelium and buffer. Both halves of the chambers were immediately filled with buffer solution (Table 2) and gassed with $95 \% \mathrm{O}_{2} / 5 \% \mathrm{CO}_{2}$ at $37^{\circ} \mathrm{C}$. Glucose was added to the serosal and mucosal sides for a final concentration of 10 $\mathrm{mmol} / \mathrm{L}$. The buffer temperature was kept constant at $37^{\circ} \mathrm{C}$ throughout the measurement.

\section{Chemicals and reagent}

Six rumen epithelial tissues were collected from each goat and treated in two groups with 3 replicates per group. Finally, 18 groups were completed with different mucosal incubation solutions as follows: $\mathrm{pH}$ (7.4, 5.5 and 5.2), HIS $\left(0,0.5\right.$ and $\left.10 \mathrm{ng} \cdot \mathrm{mL}^{-1}\right)$ and $\operatorname{LPS}\left(0,30\right.$ and $\left.60 \mathrm{KEU} \cdot \mathrm{mL}^{-1}\right)$, each alone or in combination. The different mucosal $\mathrm{pH}$ values were adjusted by adding VFA and lactic acid according to Table 3, and then using $\mathrm{HCl}$ to adjust the final $\mathrm{pH}$ value. In total, repeated measurements were made on three different incubation chambers per group. After a 20 min equilibration period, the $8 \mu \mathrm{L}$ FITC (final concentration $0.2 \mathrm{mmol} / \mathrm{L}$ ) and $8 \mu \mathrm{L} \mathrm{HRP}$ (final concentration $2 \mu \mathrm{mol} / \mathrm{L}$ ) were added to the mucosal side of each chamber. After a 20 
Table 4: Effects of different $\mathrm{pH} \times$ LPS treatments on rumen epithelial electrophysiological parameters in dairy goats $(n=3)$

\begin{tabular}{|c|c|c|c|c|}
\hline $\begin{array}{l}\text { LPS } \\
\text { content/KEU } \cdot \mathrm{mL}^{-1}\end{array}$ & $\begin{array}{l}\mathrm{pH} \\
\text { value }\end{array}$ & $\begin{array}{l}\mathrm{I}_{\mathrm{sc}} / \mathrm{mA} \\
\left(\mathrm{cm}^{2} \cdot \mathrm{h}\right)^{-1}\end{array}$ & $\begin{array}{l}\mathrm{G}_{\mathrm{l}} / \mathrm{mS} \\
\left(\mathrm{cm}^{2} \cdot \mathrm{h}\right)^{-1}\end{array}$ & $\begin{array}{l}\mathrm{PD} / \mathrm{mV} \\
\left(\mathrm{cm}^{2} \cdot \mathrm{h}\right)^{-1}\end{array}$ \\
\hline \multirow[t]{3}{*}{0} & 7.4 & $0.05^{\mathrm{d}}$ & $3.70^{\mathrm{d}}$ & $1.15^{\mathrm{d}}$ \\
\hline & 5.5 & $0.16^{\mathrm{c}}$ & $4.05^{\mathrm{bc}}$ & $1.08^{\mathrm{d}}$ \\
\hline & 5.2 & $0.46^{\mathrm{b} /}$ & $4.14^{\mathrm{bc}}$ & $6.66^{\mathrm{a}}$ \\
\hline \multirow[t]{3}{*}{30} & 7.4 & $0.03^{\mathrm{d}}$ & $2.71^{\mathrm{e}}$ & $1.74^{\mathrm{c}}$ \\
\hline & 5.5 & $0.13^{\mathrm{cd}}$ & $4.41^{\mathrm{bc}}$ & $1.24^{\mathrm{cd}}$ \\
\hline & 5.2 & $0.16^{\mathrm{c}}$ & $5.05^{\mathrm{b}}$ & $2.54^{\mathrm{b}}$ \\
\hline \multirow[t]{3}{*}{60} & 7.4 & $0.09^{\mathrm{d}}$ & $3.87^{\mathrm{bc}}$ & $2.75^{\mathrm{b}}$ \\
\hline & 5.5 & $0.15^{\mathrm{c}}$ & $4.17^{\mathrm{b}}$ & $2.44^{\mathrm{bc}}$ \\
\hline & 5.2 & $0.65^{\mathrm{a}}$ & $5.87^{\mathrm{a}}$ & $1.26^{\mathrm{d}}$ \\
\hline \multirow[t]{2}{*}{ SEM } & & 0.043 & 0.228 & 0.125 \\
\hline & & Main effects & & \\
\hline \multirow[t]{3}{*}{ LPS } & 0 & $0.22^{\mathrm{B}}$ & $3.96^{\mathrm{C}}$ & $2.96^{\mathrm{A}}$ \\
\hline & 30 & $0.11^{\mathrm{C}}$ & $4.06^{\mathrm{B}}$ & $1.84^{\mathrm{C}}$ \\
\hline & 60 & $0.30^{\mathrm{A}}$ & $4.64^{\mathrm{A}}$ & $2.16^{\mathrm{B}}$ \\
\hline \multirow[t]{3}{*}{$\mathrm{pH}$} & 7.4 & $0.06^{\mathrm{C}}$ & $3.43^{\mathrm{C}}$ & $1.88^{\mathrm{B}}$ \\
\hline & 5.5 & $0.15^{\mathrm{B}}$ & $4.21^{\mathrm{B}}$ & $1.58^{\mathrm{C}}$ \\
\hline & 5.2 & $0.42^{\mathrm{A}}$ & $5.02^{\mathrm{A}}$ & $3.49^{\mathrm{A}}$ \\
\hline \multirow[t]{3}{*}{$P$-value } & $\mathrm{pH}$ & $<.0001$ & $<.0001$ & $<.0001$ \\
\hline & LPS & $<.0001$ & $<.0001$ & $<.0001$ \\
\hline & $\mathrm{pH} \times \mathrm{LPS}$ & $<.0001$ & $<.0001$ & $<.0001$ \\
\hline
\end{tabular}

Table 5: Effects of different $\mathrm{pH} \times$ LPS treatments on rumen epithelial HRP and FITC flows and LPS content on the serosal side in dairy goats

\begin{tabular}{|c|c|c|c|c|}
\hline $\begin{array}{l}\text { LPS } \\
\text { content/KEU.mL }{ }^{-1}\end{array}$ & $\begin{array}{l}\mathrm{pH} \\
\text { value }\end{array}$ & $\begin{array}{l}\text { FITC/mmo } \\
1\left(\mathrm{~cm}^{2} \cdot \mathrm{h}\right)^{-1}\end{array}$ & $\begin{array}{l}\mathrm{HRP} / \mathrm{mol} \\
\left(\mathrm{cm}^{2} \cdot \mathrm{h}\right)^{-1}\end{array}$ & $\begin{array}{l}\text { LPS } \\
\text { content/KEU. } \mathrm{mL}^{-1}\end{array}$ \\
\hline \multirow[t]{3}{*}{0} & 7.4 & $0.15^{\mathrm{c}}$ & $0.03^{\mathrm{b}}$ & - \\
\hline & 5.5 & $0.15^{\mathrm{c}}$ & $0.12^{\mathrm{ab}}$ & - \\
\hline & 5.2 & $0.21^{\mathrm{bc}}$ & $0.10^{\mathrm{ab}}$ & - \\
\hline \multirow[t]{3}{*}{30} & 7.4 & $0.11^{\mathrm{d}}$ & $0.04^{\mathrm{b}}$ & 25.92 \\
\hline & 5.5 & $0.12^{\text {cd }}$ & $0.05^{\mathrm{b}}$ & 21.94 \\
\hline & 5.2 & $0.38^{\mathrm{ab}}$ & $0.05^{\mathrm{b}}$ & 27.91 \\
\hline \multirow[t]{3}{*}{60} & 7.4 & $0.15^{\mathrm{c}}$ & $0.05^{\mathrm{b}}$ & 29.11 \\
\hline & 5.5 & $0.18^{\mathrm{c}}$ & $0.06^{\mathrm{b}}$ & 35.75 \\
\hline & 5.2 & $0.48^{\mathrm{a}}$ & $0.16^{\mathrm{a}}$ & 26.36 \\
\hline \multirow[t]{2}{*}{ SEM } & & 0.056 & 0.042 & 3.730 \\
\hline & & Main effec & & \\
\hline \multirow[t]{3}{*}{ LPS } & 0 & $0.17^{\mathrm{C}}$ & 0.08 & - \\
\hline & 30 & $0.20^{\mathrm{B}}$ & 0.05 & $25.26^{\mathrm{B}}$ \\
\hline & 60 & $0.27^{\mathrm{A}}$ & 0.09 & $30.41^{\mathrm{A}}$ \\
\hline \multirow[t]{3}{*}{$\mathrm{pH}$} & 7.4 & $0.14^{\mathrm{B}}$ & 0.04 & $27.52^{\mathrm{B}}$ \\
\hline & 5.5 & $0.15^{\mathrm{B}}$ & 0.08 & $28.85^{\mathrm{A}}$ \\
\hline & 5.2 & $0.36^{\mathrm{A}}$ & 0.10 & $27.14^{\mathrm{B}}$ \\
\hline \multirow[t]{3}{*}{$P$-value } & $\mathrm{pH}$ & $<.0001$ & 0.099 & 0.041 \\
\hline & LPS & 0.007 & 0.101 & 0.048 \\
\hline & $\mathrm{pH} \times \mathrm{LPS}$ & 0.036 & 0.047 & 0.472 \\
\hline
\end{tabular}

epithelium. Compared with mucosal $\mathrm{pH}-\mathrm{HIS} 0.5$ groups, $\mathrm{I}_{\mathrm{sc}}$ and $\mathrm{G}_{\mathrm{t}}$ were significantly increased $(P<0.05)$ in mucosal pH-HIS 10 groups with an HIS-based effect, while PD was reduced $(P<0.05)$. When $\mathrm{pH}$ was the main factor, $\mathrm{I}_{\mathrm{sc}}$ of ruminal epithelium incubated with mucosal addition of HIScontaining solution was greatest $(P<0.05)$ at mucosal $\mathrm{pH}$ $5.2, \mathrm{G}_{\mathrm{t}}$ was greatest $(P<0.05)$ at mucosal $\mathrm{pH} 5.5$, and $\mathrm{PD}$ was lowest $(P<0.05)$ at mucosal $\mathrm{pH} 5.5$. The interaction between $\mathrm{pH}$ and HIS showed that $\mathrm{I}_{\mathrm{sc}}$ and $\mathrm{G}_{\mathrm{t}}$ of incubated
Table 6: Effects of different $\mathrm{pH} \times \mathrm{HIS}$ treatments on rumen epithelial electrophysiological parameters in dairy goats

\begin{tabular}{|c|c|c|c|c|}
\hline $\begin{array}{l}\text { HIS } \\
\text { content/ng. } \mathrm{mL}^{-1}\end{array}$ & $\begin{array}{l}\mathrm{pH} \\
\text { value }\end{array}$ & $\begin{array}{l}\mathrm{I}_{\mathrm{sc}} / \mathrm{Ma} \\
\left(\mathrm{cm}^{2} \cdot \mathrm{h}\right)^{-1}\end{array}$ & $\begin{array}{l}\mathrm{G}_{\mathrm{t}} / \mathrm{mS} \\
\left(\mathrm{cm}^{2} \cdot \mathrm{h}\right)^{-1}\end{array}$ & $\begin{array}{l}\mathrm{PD} / \mathrm{mV} \\
\left(\mathrm{cm}^{2} \cdot \mathrm{h}\right)^{-1}\end{array}$ \\
\hline \multirow[t]{3}{*}{0} & 7.4 & $0.05^{\mathrm{ef}}$ & $3.70^{\mathrm{d}}$ & $1.15^{\mathrm{d}}$ \\
\hline & 5.5 & $0.06^{\mathrm{ef}}$ & $4.05^{\mathrm{c}}$ & $1.08^{\mathrm{d}}$ \\
\hline & 5.2 & $0.31^{\mathrm{b}}$ & $4.14^{\mathrm{c}}$ & $6.66^{\mathrm{a}}$ \\
\hline \multirow[t]{3}{*}{0.5} & 7.4 & $0.02^{\mathrm{g}}$ & $3.70^{\mathrm{d}}$ & $2.92^{\mathrm{c}}$ \\
\hline & 5.5 & $0.08^{\mathrm{e}}$ & $4.35^{\mathrm{b}}$ & $0.73^{\text {de }}$ \\
\hline & 5.2 & $0.13^{\mathrm{d}}$ & $4.84^{\mathrm{a}}$ & $0.86^{\mathrm{de}}$ \\
\hline \multirow[t]{3}{*}{10} & 7.4 & $0.16^{\mathrm{d}}$ & $3.46^{\mathrm{c}}$ & $3.94^{\mathrm{b}}$ \\
\hline & 5.5 & $0.24^{\mathrm{bc}}$ & $5.93^{\mathrm{a}}$ & $0.24^{\mathrm{f}}$ \\
\hline & 5.2 & $0.46^{\mathrm{a}}$ & $4.41^{\mathrm{b}}$ & $3.43^{\mathrm{b}}$ \\
\hline \multirow[t]{2}{*}{ SEM } & & 0.022 & 0.165 & 0.290 \\
\hline & & Main effects & & \\
\hline \multirow[t]{3}{*}{ HIS } & 0 & $0.14^{\mathrm{B}}$ & $3.96^{\mathrm{C}}$ & $2.96^{\mathrm{A}}$ \\
\hline & 0.5 & $0.08^{\mathrm{B}}$ & $4.30^{\mathrm{B}}$ & $1.50^{\mathrm{C}}$ \\
\hline & 10 & $0.29^{\mathrm{A}}$ & $4.60^{\mathrm{A}}$ & $2.54^{\mathrm{B}}$ \\
\hline \multirow[t]{3}{*}{$\mathrm{pH}$} & 7.4 & $0.08^{\mathrm{C}}$ & $3.62^{\mathrm{C}}$ & $2.67^{\mathrm{B}}$ \\
\hline & 5.5 & $0.13^{\mathrm{B}}$ & $4.78^{\mathrm{A}}$ & $0.68^{\mathrm{C}}$ \\
\hline & 5.2 & $0.30^{\mathrm{A}}$ & $4.46^{\mathrm{B}}$ & $3.65^{\mathrm{A}}$ \\
\hline \multirow[t]{3}{*}{$P$-value } & $\mathrm{pH}$ & $<.0001$ & $<.0001$ & $<.0001$ \\
\hline & HIS & 0.001 & $<.0001$ & $<.0001$ \\
\hline & $\mathrm{pH} \times \mathrm{HIS}$ & $<.0001$ & $<.0001$ & $<.0001$ \\
\hline
\end{tabular}

Table 7: Effects of different $\mathrm{pH} \times \mathrm{HIS}$ treatments on rumen epithelial HRP and FITC flows and HIS content in the serosal side in dairy goats

\begin{tabular}{|c|c|c|c|c|}
\hline $\begin{array}{l}\mathrm{HIS \quad cc} \\
/ \mathrm{ng} \cdot \mathrm{mL}^{-1}\end{array}$ & $\begin{array}{l}\mathrm{pH} \\
\text { value }\end{array}$ & $\begin{array}{l}\text { FITC/mmol } \\
\left(\mathrm{cm}^{2} \cdot \mathrm{h}\right)^{-1}\end{array}$ & $\begin{array}{l}\mathrm{HRP} / \mathrm{mol} \\
\left(\mathrm{cm}^{2} \cdot \mathrm{h}\right)^{-1}\end{array}$ & $\begin{array}{l}\text { HIS } \\
\text { content/ng. } \mathrm{mL}^{-1}\end{array}$ \\
\hline \multirow[t]{3}{*}{0} & 7.4 & $0.15^{\mathrm{bc}}$ & $0.03^{\mathrm{c}}$ & - \\
\hline & 5.5 & $0.15^{\mathrm{bc}}$ & $0.14^{\mathrm{a}}$ & - \\
\hline & 5.2 & $0.21^{\mathrm{a}}$ & $0.10^{\mathrm{b}}$ & - \\
\hline \multirow[t]{3}{*}{0.5} & 7.4 & $0.17^{\mathrm{ab}}$ & $0.09^{\mathrm{b}}$ & 0.15 \\
\hline & 5.5 & $0.13^{\text {cd }}$ & $0.09^{\mathrm{b}}$ & 0.12 \\
\hline & 5.2 & $0.12^{\mathrm{cd}}$ & $0.08^{\mathrm{b}}$ & 0.12 \\
\hline \multirow[t]{3}{*}{10} & 7.4 & $0.14^{\mathrm{bc}}$ & $0.12^{\mathrm{ab}}$ & 0.13 \\
\hline & 5.5 & $0.13^{\text {cd }}$ & $0.02^{\mathrm{c}}$ & 0.13 \\
\hline & 5.2 & $0.09^{\mathrm{d}}$ & $0.14^{\mathrm{a}}$ & 0.14 \\
\hline \multicolumn{2}{|l|}{ SEM } & 0.013 & 0.026 & 0.009 \\
\hline \multicolumn{5}{|c|}{ Main effects } \\
\hline \multirow[t]{3}{*}{ HIS } & 0 & $0.17^{\mathrm{A}}$ & 0.09 & - \\
\hline & 0.5 & $0.14^{\mathrm{B}}$ & 0.09 & 0.13 \\
\hline & 10 & $0.12^{\mathrm{C}}$ & 0.09 & 0.14 \\
\hline \multirow[t]{3}{*}{$\mathrm{pH}$} & 7.4 & $0.16^{\mathrm{A}}$ & 0.10 & 0.14 \\
\hline & 5.5 & $0.13^{\mathrm{B}}$ & 0.08 & 0.13 \\
\hline & 5.2 & $0.14^{\mathrm{B}}$ & 0.11 & 0.13 \\
\hline \multirow[t]{3}{*}{$P$-value } & $\mathrm{pH}$ & 0.001 & 0.052 & 0.275 \\
\hline & HIS & 0.021 & 0.710 & 0.253 \\
\hline & $\mathrm{pH} \times \mathrm{HIS}$ & 0.451 & 0.050 & 0.097 \\
\hline
\end{tabular}

ruminal epithelium were the highest $(P<0.05)$ at mucosal $\mathrm{pH}$ 5.2-HIS 10 and at mucosal $\mathrm{pH}$ 5.5-HIS 10, respectively, and the PD was lowest $(P<0.05)$ at mucosal pH 5.5-HIS 10.

Table 7 summarizes data for the mucosal-to-serosal fluxes of FITC and HRP. When HIS was the main factor, the FITC flow rate from mucosal to serosal was greater $(P<$ 0.05 ) in mucosal HIS 0.5 than that in mucosal HIS 10, while the HRP flow rate remained consistent. When $\mathrm{pH}$ was the main factor, the FITC flow rate of ruminal epithelium 
Table 8: Effects of different $\mathrm{pH} \times$ LPS $\times$ HIS treatments on rumen epithelial electrophysiological parameters in dairy goats

\begin{tabular}{llll}
\hline $\mathrm{pH} \times \mathrm{LPS} \times \mathrm{HIS}$ treatments & $\begin{array}{l}\mathrm{I}_{\mathrm{sc}} / \mathrm{Ma} \\
\left(\mathrm{cm}^{2} \cdot \mathrm{h}\right)^{-1}\end{array}$ & $\begin{array}{l}\mathrm{G}_{\mathrm{t}} / \mathrm{mS} \\
\left(\mathrm{cm}^{2} \cdot \mathrm{h}\right)^{-1}\end{array}$ & $\begin{array}{l}\mathrm{PD} / \mathrm{mV} \\
\left(\mathrm{cm}^{2} \cdot \mathrm{h}\right)^{-1}\end{array}$ \\
\hline $7.4 \times 60 \mathrm{KEU} \cdot \mathrm{mL}^{-1} \times 10 \mathrm{ng} \cdot \mathrm{mL}^{-1}$ & $0.31^{\mathrm{c}}$ & $4.16^{\mathrm{b}}$ & $0.36^{\mathrm{b}}$ \\
$5.5 \times 60 \mathrm{KEU} \cdot \mathrm{mL}^{-1} \times 10 \mathrm{ng} \cdot \mathrm{mL}^{-1}$ & $0.76^{\mathrm{a}}$ & $3.79^{\mathrm{c}}$ & $0.28^{\mathrm{c}}$ \\
$5.2 \times 60 \mathrm{KEU} \cdot \mathrm{mL}^{-1} \times 10 \mathrm{ng} \cdot \mathrm{mL}^{-1}$ & $0.52^{\mathrm{b}}$ & $5.03^{\mathrm{a}}$ & $1.49^{\mathrm{a}}$ \\
$\mathrm{SEM}$ & 0.004 & 0.108 & 0.114 \\
$P$-value & $<.0001$ & $<.0001$ & $<.0001$ \\
\hline${ }^{\mathrm{a}-\mathrm{c}}$ Means with different superscript letters differ significantly $(P<0.05)$ & \\
${ }^{1} \mathrm{I}_{\text {sc }}=$ short-circuit current & & \\
${ }^{2} \mathrm{G}_{\mathrm{t}}=$ tissue conductance & & \\
${ }^{3} \mathrm{HRP}=$ horseradish peroxidase & & \\
${ }^{4} \mathrm{FTC}=$ fluorescein isothiocyanate & & \\
\end{tabular}

Table 9: Effects of different $\mathrm{pH} \times$ LPS $\times$ HIS treatments on rumen epithelial HRP and FITC flows and LPS and HIS contents in the serosal side in dairy goats

\begin{tabular}{lllll}
\hline $\mathrm{pH} \times \mathrm{LPS} \times \mathrm{HIS}$ treatments & $\begin{array}{l}\text { FITC/mmol } \\
\left(\mathrm{cm}^{2} \cdot \mathrm{h}\right)^{-1}\end{array}$ & $\begin{array}{l}\mathrm{HRP} / \mathrm{mol} \\
\left(\mathrm{cm}^{2} \cdot \mathrm{h}\right)^{-1}\end{array}$ & $\begin{array}{l}\mathrm{LPS} / \mathrm{KE} \\
\mathrm{U} \cdot \mathrm{mL}^{-1}\end{array}$ & $\begin{array}{l}\mathrm{HIS} / \mathrm{ng} \cdot \\
\mathrm{mL}^{-1}\end{array}$ \\
\hline $7.4 \times 60 \mathrm{KEU} \cdot \mathrm{mL}^{-1} \times 10 \mathrm{ng} \cdot \mathrm{mL}^{-1}$ & $0.62^{\mathrm{b}}$ & 0.18 & 41.94 & 0.29 \\
$5.5 \times 60 \mathrm{KEU} \cdot \mathrm{mL}^{-1} \times 10 \mathrm{ng} \cdot \mathrm{mL}^{-1}$ & $0.68^{\mathrm{a}}$ & 0.25 & 35.83 & 0.19 \\
$5.2 \times 60 \mathrm{KEU} \cdot \mathrm{mL}^{-1} \times 10 \mathrm{ng} \cdot \mathrm{mL}^{-1}$ & $0.60^{\mathrm{b}}$ & 0.39 & 41.18 & 0.19 \\
$\mathrm{SEM}$ & 0.020 & 0.094 & 2.242 & 0.045 \\
$P$-value & 0.012 & 0.275 & 0.09 & 0.241 \\
\hline
\end{tabular}

Means with different lowercase letters are significantly different, means with different $(P<0.05)$. Uppercase letters within the same column are significantly different

incubated with mucosal addition of HIS-containing solution at mucosal $\mathrm{pH} 5.2$ was lowest $(P<0.05)$, while the HRP flow rate was highest $(P<0.05)$. The interaction between $\mathrm{pH}$ and HIS showed that the mucosal-to-serosal flux of FITC at mucosal pH 5.5-HIS 10 was increased compared with mucosal $\mathrm{pH}$ 5.2-HIS 10, whereas the HRP flow rate was decreased, and the concentration of HIS in the serosal side showed no significant change (Table 7).

\section{Interactions of pH, LPS and HIS on rumen epithelial permeability}

As seen in Table 8, 9 the co-presence of pH, LPS and HIS had a significant effect on $\mathrm{I}_{\mathrm{sc}}, \mathrm{G}_{\mathrm{t}}$ and PD of the incubated ruminal epithelium. $\mathrm{I}_{\mathrm{sc}}$ was the highest in $\mathrm{pH}$ 5.5-LPS 60HIS 10, whereas PD was the lowest, and the difference between the treatments was significant $(P<0.05) . \mathrm{G}_{\mathrm{t}}$ reached the highest level $(P<0.05)$ in $\mathrm{pH} 5.2$-LPS 60HIS10.

The FITC flow rate of the incubated rumen epithelium was greatest $(P<0.05)$ in $\mathrm{pH} 5.5$-LPS 60 -HIS 10 . The HRP flow rate was greater at mucosal $\mathrm{pH} 5.2$ than for the other groups. No significant differences among the treatments were observed for the concentrations of LPS and HIS in the serosal side (Table 9).

\section{Discussion}

Previous reports have clearly shown that SARA can compromise the rumen epithelial barrier and increase rumen epithelial permeability (Steele et al. 2011; Klevenhusen et al.
2013; Meissner et al. 2017; Sun et al. 2018a). One of our previous studies from the same experiment demonstrated that $\mathrm{pH}$ interacts with both HIS and LPS to decrease the abundance of mRNA for genes involved in tight junction protein of the ruminal epithelium, which are probably related to increases in the permeability of the ruminal epithelium (Sun et al. 2018b). In the present study, we provide evidence that concurrent presence of low $\mathrm{pH}$ with excessive LPS and HIS in the rumen might the main trigger for increased rumen epithelial permeability.

The ruminal epithelium is a stratified squamous epithelium consisting of four distinct strata with a junctional complex that forms a barrier between the luminal contents and the internal milieu. As a permeable barrier, its role is to facilitate absorption of ions, water and nutrients, while at the same time preventing paracellular permeation of microorganisms and toxic compounds including LPS (Amaral et al. 2007; Liu et al. 2013). The Ussing chamber could indicate the permeability of the ruminal epithelium by the measurement of electrophysiological parameters (Vidyasagar and MacGregor 2016). Increased $I_{\mathrm{sc}}$ indicates an increase in the transport capacity of ions through the epithelium, and significantly increased $G_{t}$ after rumen mucosal acidification indicates impaired rumen epithelial barrier function and increased epithelial permeability. Since the PD value is positively proportional to the epithelial resistance, the epithelial resistance can represent the tight junction of the epithelial intercellular and paracellular permeability and can also be used to monitor the rumen epithelial activity of ruminants (Ussing and Zerahn 1951). In the present study, the Ussing chamber technique was used to monitor rumen epithelial permeability in terms of $\mathrm{I}_{\mathrm{sc}}$, $G_{t}$ and PD of the incubated ruminal epithelium and the fluxes of HRP and FITC. Our results indicated that the $I_{s c}$, as a measure of active electrogenic electrolyte transport, as well as the $G_{t}$, as a measure of passive ion permeability, significantly increased in the concurrent presence of low mucosal $\mathrm{pH}$ with excessive addition of LPS and HIS, which indicated that the rumen epithelial barrier functions were profoundly compromised.

Ruminal pH, VFA, osmolarity and LPS concentration have been suggested as triggers for impairment of the rumen epithelial barrier, because they are known to be detrimental for the rumen epithelial barrier (Penner et al. 2011; Greco et al. 2018). Of these, the ruminal $\mathrm{pH}$ clearly plays a crucial role and impairs epithelial barrier function as indicated by increased permeability of the ruminal epithelium (Penner $e t$ al. 2010). An in vivo study conducted by Klevenhusen et al. (2013) demonstrated that low $\mathrm{pH}$ is a primary event preceding LPS release and LPS translocation across the rumen epithelial barrier during SARA (Enemark et al. 2002). In this study, $\mathrm{pH}$, LPS and HIS were applied to healthy ruminal epithelium in vitro on a short-term basis. As a result of the single factor of $\mathrm{pH}$, rumen epithelial permeability increased, and tissue activity decreased with a decrease of mucosal $\mathrm{pH}$. Moreover, low mucosal $\mathrm{pH}$ in combination 
with $60 \mathrm{KEU} \cdot \mathrm{mL}^{-1} \mathrm{LPS}$ induced a higher permeability of the ruminal epithelium, again suggesting that the influence of both $\mathrm{pH}$ and LPS on the rumen epithelial permeability was greater than that of $\mathrm{pH}$ alone. This may indicate that the combined effect of LPS and $\mathrm{pH}$ in the rumen of goats suffering from SARA aggravated the destruction of the ruminal epithelium. The ruminal LPS concentration has been found to increase to $26,915 \mathrm{EU} / \mathrm{mL}$ when SARA was induced (Gozho et al. 2006). SARA was the main cause of rumen epithelial barrier dysfunction, which is associated with low $\mathrm{pH}$ and high osmotic pressure (Aschenbach et al. 1998; Dong et al. 2013). In addition, HIS or inflammatory responses during acidosis can also impair the barrier function of the ruminal epithelium.

HIS is produced by the decarboxylation of histidine catalyzed by histidine decarboxylase. Under normal physiological conditions, the body generally contains HIS, but in very small amounts (Slyter 1976; Martens et al. 1987). Trace amounts of HIS can be involved in the collective regulation of a variety of physiological functions, such as nerve, endocrine, gastrointestinal and circulatory regulation (Klingspor et al. 2013). The notion that SARA is accompanied by the increase of abnormal metabolites, such as HIS, is widely accepted. When there is so much HIS in the rumen that it exceeds the normal metabolic capacity of the body, HIS will be transported into the blood circulation through the damaged ruminal epithelium and cause inflammation. This further aggravates the SARA and causes the further destruction of the ruminal epithelium (Gozho et al. 2007).

Cheng (2016) showed that in dairy goats the concentrations of LPS and HIS in plasma and rumen were significantly increased during grain-induced SARA. The increased HIS or LPS translocating from the gastrointestinal tract into the blood can down-regulate the expression of gastrointestinal tight junction protein and embedded protein, and increase the apoptosis rate of epithelial cells, resulting in further damage of the epithelial barrier (Pilachai et al. 2012). Aschenbach et al. (1998) showed that HIS-induced apoptosis increased cell shedding and interfered with nuclear division and cell maturation. This might mean that HIS could interfere with the regeneration of epithelial cells during SARA, thus causing cell damage and triggering an inflammatory reaction. In the present study, our data showed that the rumen epithelial permeability was significantly increased, and tissue activity was reduced in mucosal $\mathrm{pH}$ 5.2-HIS 10. This suggests that lower mucosal $\mathrm{pH}$ with excessive HIS induced more severe barrier dysfunction. Our data are similar with the results of Penner et al. (2010) and Meissner et al. (2017), which indicated a low $\mathrm{pH}$ of 5.2 has only moderate effects on the ruminal epithelial barrier, whereas concurrent presence of low $\mathrm{pH}$ with high SCFA concentrations can trigger a profound impairment of epithelial barrier function ( $\mathrm{Hu} 2008$; $\mathrm{Hu}$ et al. 2015). Therefore, we concluded that the disruption of the rumen epithelial barrier function was not caused only by $\mathrm{pH}$, and the concurrent presence of pH-HIS or pH-LPS might contribute to the more obvious increases of rumen epithelial permeability in the present study.

Additionally, the permeability of marker molecules of different sizes (HRP as a large marker, FITC as a small marker) was also measured in the present study. Compared with mucosal $\mathrm{pH}$ alone or concurrent presence of $\mathrm{pH}$-LPS and $\mathrm{pH}-\mathrm{HIS}$, significant increases in mucosal-to-serosal fluxes of HRP and FITC coupled with enhanced $I_{s c}$ and $G_{t}$ were observed in the concurrent presence of mucosal $\mathrm{pH}$ with LPS and HIS. An increased flux of FITC or HRP reflects increased paracellular permeability and impaired ruminal barrier. Our results further suggested that the combined treatment of $\mathrm{pH}$, LPS and HIS contributes to triggering higher epithelial permeability and more profound barrier dysfunction. Thus, subacute rumen acidosis is a process involving $\mathrm{pH}$, LPS, HIS and their synergistic interactions. One of our previous studies in dairy goats reported that a concurrent increase of both HRP and FITC mucosal-to-serosal flux rates were observed during SARA (Sun et al. 2018b), which is somewhat inconsistent with the results of the present study. In the short-term $\mathrm{pH} \times \mathrm{LPS} \times \mathrm{HIS}$ cross-treatment, the small molecule (FITC) permeability of the incubated ruminal epithelium was increased, but the permeability to large molecules (HRP) was not increased significantly. This observation may also be related to the different absorption mechanisms of large and small molecular markers by ruminal epithelium in the short term. In order to ensure the health of the animal, the ruminal epithelium may normally prevent penetration of large molecule toxic substances and only allow small molecules, such as amino acids and water, to pass through (Oba et al. 2005).

\section{Conclusion}

Our results have shown an increased rumen epithelial permeability during SARA is caused by the combined action of low $\mathrm{pH}$ with high LPS and high HIS concentrations, which is critical for the impairment of the rumen epithelial barrier. Our study also showed that concurrent presence of LPS $60 \mathrm{KEU} \cdot \mathrm{mL}^{-1}$ and HIS $10 \mathrm{ng} \cdot$ $\mathrm{mL}^{-1}$ at mucosal $\mathrm{pH} 5.5$ can aggravate rumen epithelial barrier dysfunction.

\section{Acknowledgments}

This research was supported by grants from China National Natural Science Foundation of China (no. 31101739and no. 31472124), Inner Mongolia Natural Science foundation (no. 2019MS03031), China Agriculture Research System (no. CARS-36), Innovation Fund of Inner Mongolia Agricultural and Animal Husbandry (no. 2021CXJJM02) and Open Project of Beijing Key Laboratory of Dairy Cow Nutrition, Beijing University of Agriculture. The authors declare no conflict of interest in this study. 


\section{Author Contributions}

We thank study participants for their contribution, Y.Y. Sun: writing-original draft preparation and writing-reviewing \& editing, M. Gao: supervision and project administration, L.W. Song, M. Xu, C. Li, Y. Li, and L.Q. Chen: experimental sample and data collation, H.L. Hu: Writingreviewing and editing and L.S. Jiang: funding acqusition.

\section{Conflict of Interest}

The authors declare no conflict of interest in this study

\section{Data Availability}

All data presented in this study are available upon request

\section{Ethics Approval}

The experimental design and procedures were approved by the Animal Care and Use Committee of the Inner Mongolia Academy of Agricultural and Animal Husbandry Sciences and were performed in accordance with relevant guidelines formulated by the Ministry of Agriculture of the People's Republic of China.

\section{Funding Source}

This study was supported by grants from China National Natural Science Foundation of China (no. 31101739 and no. 31472124), Inner Mongolia Natural Science foundation (no. 2019MS03031), China Agriculture Research System (no. CARS-36), Innovation Fund of Inner Mongolia Agricultural and Animal Husbandry (no. 2021CXJJM02) and Open Project of Beijing Key Laboratory of Dairy Cow Nutrition, Beijing University of Agriculture. The authors declare no conflict of interest in this study.

\section{References}

Amaral MM, C Davio, A Ceballos, G Salamone, C Cañones, J Geffner, M Vermeulen (2007). Histamine improves antigen uptake and crosspresentation by dendritic cells. J Immunol 179:3425-3433

Aschenbach JR, Q Zebeli, AK Patra, G Greco, S Amasheh, GB Penner (2019). Symposium review: The importance of the ruminal epithelia barrier for a healthy and productive cow. J Dairy Sci 102:1866-1882

Aschenbach JR, B Fürll, G Gäbel (1998). Histamine affects growth of sheep ruminal epithelial cells kept in primary culture. Zentr Vet Reihe A 45:411-416

Cheng M (2016). Effect of subacute ruminal acidosis on rumen epithelium permeability and intercellular junction protein expression in dairy goats. Thesis. Inner Mongolia Agriculture University, Hohhot, China

Danscher AM, S Li, PH Andersen, E Khafipour, NB Kristensen, JC Plaizier (2015). Indicators of induced subacute ruminal acidosis (SARA) in Danish Holstein cows. Acta Vet Scand 57:39-52

Dong G, S Liu, Y Wu, C Lei, J Zhou, S Zhang (2011). Diet-induced bacterial immunogens in the gastrointestinal tract of dairy cows: Impacts on immunity and metabolism. Acta Vet Scand 53:48-54
Dong H, SQ Wang, YY Jia, YD Ni, YS Zhang, S Zhang, XZ Shen, RQ Zhao (2013). Long-term effects of subacute ruminal acidosis (SARA) on milk quality and hepatic gene expression in lactating goats fed a high-concentrate diet. PLoS One 8; Article e82850

Emmanuel DG, KL Madsen, TA Churchill, SM Dunn, BN Ametaj (2007). Acidosis and lipopolysaccharide from Escherichia coli B: 055 cause hyperpermeability of rumen and colon tissues. J Dairy Sci 90:5552-5557

Enemark JMD, RJ Jorgensen, PS Enemark (2002). Rumen acidosis with special emphasis on diagnostic aspects of subclinical rumen acidosis: A review. Vet Zoot 20:16-29

Gaebel G, M Bell, H Martens (1989). The effect of low mucosal pH on sodium and chloride movement across the isolated rumen mucosa of sheep. Quart J Exp Physiol 74:35-55

Gozho GN, DO Krause, JC Plaizier (2007). Ruminal lipopolysaccharide concentration and inflammatory response during grain-induced subacute ruminal acidosis in dairy cows. J Dairy Sci 90:856-866

Gozho GN, DO Krause, JC Plaizier (2006). Rumen lipopolysaccharide and inflammation during grain adaptation and subacute ruminal acidosis in steers. J Dairy Sci 89:4404-4413

Greco G, F Hagen, S Meißner, ZM Shen, ZY Lu, S Amasheh, JR Aschenbach (2018). Effect of individual SCFA on the epithelial barrier of sheep rumen under physiological and acidotic luminal $\mathrm{pH}$ conditions. J Anim Sci 96:126-142

$\mathrm{Hu}$ HL (2008). Study on the physiological mechanism of nutritive physiological mechanism of subacute rumen of milk goats. Thesis Inner Mongolia Agriculture University, Hohhot, China

Hu HL, TY Xie, SQ Yang, M Gao, YC Yao (2015). Effect of subacute rumen acidosis on plasma cytokines and hormone content of goats Chin J Anim Nutr 27:418-425

Khafipour E, DO Kraure, JC Plaizier (2009). A grain-based subacute ruminal acidosis challenge causes translocation of lipopolysaccharide and triggers inflammation. J Dairy Sci 92:1060-1070

Klevenhusen F, M Hollmann, L Podstatzky-lichtenstein, R Krametterfrotscher, JR Aschenbach, Q Zebeli (2013). Feeding barley grainrich diets altered electrophysiological properties and permeability of the ruminal wall in a goat model. J Dairy Sci 96:2293-2302

Klingspor S, H Martens, D Caushi, S Twardziok, JR Aschenbach, U Lodemann (2013). Characterization of the effects of Enterococcus faecium on intestinal epithelial transport properties in piglets. $J$ Anim Sci 91:25-27

Liu JH, TT Xu, YJ Liu, WY Zhu, SY Mao (2013). A high-grain diet causes massive disruption of ruminal epithelial tight junctions in goats. Amer J Physiol Regul Integr Compar Physiol 305:232-241

Lodemann U, H Martens (2006). Effects of diet and osmotic pressure on $\mathrm{Na}^{+}$transport and tissue conductance of sheep isolated rumen epithelium. Exp Physiol 91:539-550

Martens H, G Gabel, H Strozyk (1987). The effect of potassium and the transmural potential difference on magnesium transport across an isolated preparation of sheep rumen epithelium. Quart J Exp Physiol $72: 181-188$

Meissner S, F Hagen, C Deiner, D Gunzel, G Greco, ZM Shen, JR Aschenbach (2017). Key role of short-chain fatty acids in epithelial barrier failure during ruminal acidosis. J Dairy Sci 100:6662-6675

NRC (2007). Nutruent requirements of Small Ruminants: Sheep, Goats, Cervids, and New World Camelids. National Academy Press, Washington DC, USA

Oba M, RL Baldwin, SL Owens, BJ Bequette (2005). Metabolic fates of ammonia-N in ruminal epithelial and duodenal mucosal cells isolated from growing sheep. J Dairy Sci 88:3963-3970

Penner GB, MA Steele, JR Aschenbach, BW McBride (2011). Ruminant nutrition symposium: Molecular adaptation of ruminal epithelia to highly fermentable diets. J Anim Sci 89:1108-1119

Penner GB, M Oba, G Gäbel, JR Aschenbach (2010). A single mild episode of subacute ruminal acidosis does not affect ruminal barrier function in the short term. J Dairy Sci 93:4838-4845

Plaizier JC, E Khafipour, S Li, GN Gozho, DO Krause (2012). Subacute ruminal acidosis (SARA), endotoxins and health consequences Anim Feed Sci Technol 172:9-21 
Pilachai R, JT Schonewille, C Thamrongyoswittayakul, S Aiumlamai, C Wachirapakorn, H Everts, WH Hendriks (2012). The effects of high levels of rumen degradable protein on rumen $\mathrm{pH}$ and histamine concentrations in dairy cows. J Anim Physiol Anim Nutr 96:206-213

Sato S (2016). Pathophysiological evaluation of subacute ruminal acidosis (SARA) by continuous ruminal $\mathrm{pH}$ monitoring. Anim Sci J $87: 168-177$

Slyter LL (1976). Influence of acidosis on rumen function. J Anim Sci 43:910-929

Steele MA, J Croom, M Kahler, O Alzahal, SE Hook, K Plaizier, BW Mcbride (2011). Bovine rumen epithelium undergoes rapid structural adaptations during grain-induced subacute ruminal acidosis. Amer $J$ Physiol Regul Integr Compar Physiol 300:1515-1523

Sun YY (2017). Mechanism research on rumen epithelial permeability by subacute ruminal acidosis in dairy goats. Thesis. Inner Mongolia Agriculture University, Hohhot, China

Sun YY, M Gao, M Xu, LW Song, Y Li, C Li, LQ Chen, HL Hu (2018a). Interaction effects of $\mathrm{pH}$ and lipopolysaccharide or histamine on mRNA expression levels of tight junction proteins of rumen epithelium of dairy goats in vitro. Chin J Anim Nutr 30:1816-1826
Sun YY, C Meng, M Xu, LW Song, M Gao, HL Hu (2018b). The effects of subacute ruminal acidosis on rumen epithelial barrier function in dairy goats. Small Rumin Res 169:1-7

Tao SY, YQ Duanmu, HB Dong, YD Ni, J Chen, XZ Shen, RQ Zhao (2014). High concentrate diet induced mucosal injuries by enhancing epithelial apoptosis and inflammatory response in the hindgut of goats. PLoS One 9; Article e111596

Ussing HH, K Zerahn (1951). Active transport of sodium as the source of electric current in the short-circuited isolated frog skin. Acta Physiol Scand 23:110-127

Vidyasagar S, G MacGregor (2016). Ussing chamber technique to measure intestinal epithelial permeability. Meth Mol Biol 1422:49-61

Wang LF, SD Jia, GQ Yang, HS Zhu, RY Liu, P Yan, M Li, GY Yang (2015). Study on the effect of lipopolysaccharide on hepatic metabolism in dairy goat liver. Sci Agric Sin 48:3701-3710

Wang MY, Y Li, M Gao, LW Song, M Xu, XL Zhao, Y Jia, M Zhao, YY Sun, HL Hu (2021). Effects of subacute ruminal acidosis on colon epithelial morphological structure, permeability, and expression of key tight junction proteins in dairy goats. $J$ Dairy $S c i$ 104:4260-4270 